\title{
Study of $m c r-1$ Gene-Mediated Colistin Resistance in Enterobacteriaceae Isolated from Humans and Animals in Different Countries
}

\author{
Linda Hadjadj ${ }^{1}$, Toilhata Riziki ${ }^{1}$, Yan Zhu ${ }^{2}$, Jian $\mathrm{Li}^{2}$, Seydina M. Diene ${ }^{1}$ (D) and \\ Jean-Marc Rolain 1,* \\ 1 Unité de Recherche sur les Maladies Infectieuses et Tropicales Émergentes (URMITE), UMR CNRS, IHU \\ Méditerranée Infection, Faculté de Médecine et de Pharmacie, Aix-Marseille-University, Marseille 13005, \\ France; linda.hadjadj@univ-amu.fr (L.H.); t.riziki@yahoo.com (T.R.); seydina.m.ddiene@gmail.com (S.M.D.) \\ 2 Monash Biomedicine Discovery Institute, Department of Microbiology, Monash University, Parkville, \\ Victoria 3800, Australia; yan.zhu@monash.edu (Y.Z.); jian.li@monash.edu (J.L.) \\ * Correspondence: jean-marc.rolain@univ-amu.fr; Tel.: +33-4-9132-4375; Fax: +33-4-9138-7772
}

Academic Editor: Bruno González-Zorn

Received: 4 October 2017; Accepted: 12 December 2017; Published: 19 December 2017

\begin{abstract}
In this study, we aim to characterize the genetic environment of the plasmid-mediated colistin resistance gene $m c r-1$ in 25 Escherichia coli and seven Klebsiella pneumoniae strains from different countries and continents. Multilocus sequence typing, conjugation experiments, plasmid typing, and the presence and location of the insertion sequence ISApl1 were investigated. Whole genome sequencing of four $E$. coli was performed to analyse the genetic environment of the $m c r-1$ gene. Colistin minimum inhibitory concentration of $m c r-1$ strains varied from 3 to $32 \mu \mathrm{g} / \mathrm{mL}$. Six E. coli sequence types were detected: ST 4015, ST 3997, ST 10, ST 93, ST 48, and ST 648. IncHI2, IncI2, and IncP plasmid types were predominant and were unrelated to a specific country of origin. ISApl1 was found in $69 \%$ of analysed plasmids that were mainly around the $m c r-1$ gene. Analysis of four closed $m c r-1$ plasmids revealed the integration of $m c r-1$ into hotspots. We found that the spread of mcr-1 gene was due to the diffusion of a composite transposon and not to the diffusion of a specific plasmid or a specific bacterial clone. The ease with which the $m c r-1$ gene integrates into various regions facilitates its dissemination among bacteria and explains its large diffusion all over the world, both in animals and in humans.
\end{abstract}

Keywords: $m c r-1$; colistin; genome; integration; ISApl1; plasmid

\section{Introduction}

Antibiotic resistance is a major issue around the world. This phenomenon has led clinicians to adapt treatment strategies and to use powerful, broad spectrum antibiotics, such as carbapenems against multi drug resistant Gram-negative bacteria. However, the recent emergence of carbapenemase-producing bacteria around the world [1] has obliged clinicians to turn, as a last resort, to colistin [2,3]. The re-use of colistin has led to the appearance of colistin resistance, which is mediated by complex chromosomal resistance mechanisms in human and animal isolates [4,5]. Recently, a transferable colistin resistance mechanism, due to the presence of $m c r-1$ genes and variants that code for a phosphoethanolamine transferase, which have been detected in all continents [5] on a plasmid, has been described [6-11]. Initially, the mcr-1 gene was carried on IncI2-type plasmid, but has also been found in other plasmid types, such as IncHI2, IncX4, and IncP [5,12,13]. Generally, the $m c r-1$ gene has been described as being associated with an open reading frame (ORF), encoding a protein that is similar to a PAP2 superfamily protein, following the $m c r-1$ gene with an insertion 
sequence ISApl1 downstream to it [6]. ISApl1 is an insertion sequence that belongs to the IS30 family of transposons and was initially described in Actinobacillus pleuropneumoniae [14]. The mor-1 gene may be surrounded by two copies of ISApl1, leading to the formation of a composite transposon. This transposon Tn6330 (ISApl1-mcr-1-ORF-ISApl1) has been described as a composite transposon that is able to mobilize the $m c r-1$ gene $[15,16]$. However, to date, the integration of this transposon into plasmids, its stabilization, and its evolution have not been comprehensively described. Thus, the aim of our study was to conduct an epidemiological and molecular characterization of $m c r-1$ strains from different origins, and to study the genetic environment of the $m c r-1$ gene and to characterize four different plasmids mediating colistin resistance for a better understanding of the integration of the $m c r-1$ gene into plasmids.

\section{Materials and Methods}

\subsection{Strains}

Thirty-two mcr-1 positive strains, including 25 Escherichia coli and seven Klebsiella pneumoniae, from Laos, Thailand, France, and Algeria, as well as from Hajj pilgrims (returning from their pilgrimage from Saudi Arabia to France), were analysed [17-22]. Five isolates were from animals and 27 from humans (Table 1). The minimum inhibitory concentration (MIC) of colistin was tested by microdilution in accordance with European Committee on Antimicrobial Susceptibility Testing (EUCAST) recommendations [23]. The presence of the $m c r-1$ gene was confirmed by real-time polymerase chain reaction (RT-PCR) [24] and multilocus sequence typing performed using the Warwick method [25] on E. coli strains and the Pasteur method [26] on K. pneumoniae strains. Resistance stability was analysed by subculture over the course of 30 passages of each strain and by checking for the presence of the $m c r-1$ gene every five passages. In the event of gene loss, the MIC of colistin was tested and the procedure was repeated to confirm the results.

\subsection{Conjugation and Plasmid Analysis}

Conjugation was tested with azide-resistant E. coli J53. Transconjugants were selected on MacConkey agar (Beckton Dickinson, Le Pont de Claix, France) added by $120 \mu \mathrm{g} / \mathrm{mL}$ sodium azide and $4 \mu \mathrm{g} / \mathrm{mL}$ colistin, as described [27]. In the event of unsuccessful conjugation, transformation using the electroporation method was performed [28]. Transformants bacteria were selected on Luria Bertani agar (Beckton Dickinson, Le Pont de Claix, France) supplemented with $4 \mu \mathrm{g} / \mathrm{mL}$ colistin (Sigma-Aldrich, Saint Louis, USA). The presence of the mcr-1 gene was tested by RT-PCR on transconjugant and transformant strains. Plasmid typing was carried out on positives. Nineteen different plasmid types, including IncI2 [29,30], and the presence of the ISApl1 insertion sequence both downstream and upstream of the $m c r-1$ gene were tested by conventional PCR [31].

\subsection{Whole Genome Analysis}

Four E. coli strains (1RC4, LH1, LH30, LH57), one isolated from Hajj pilgrims, and three from healthy individuals living in Laos (Table 1), were sequenced using the Next Generation Sequencing (NGS) Miseq (Illumina Inc., San Diego, CA, USA). We selected the strain E. coli LH1 because conjugation and transformation experiments failed and we suspected a chromosomal location of $m c r-1$ gene. The strain E. coli LH30 was chosen to understand the rapid loss of $m c r-1$ gene in the resistance stability experiment. We chose the strain E. coli LH57 because a chromosomal mechanism of colistin resistance was described in this strain. The strain E. coli 1RC4 was acquired during Hajj pilgrims, and we found the origin of this plasmid. Genomes were assembled using the A5 pipeline, annotated by RAST [32], resistance gene by ARG-ANNOT [33], plasmid presence by Plasmid finder software, and plasmid multilocus sequence typing by pMLST software [34]. The percentage of similarity between plasmids was calculated using a pairwise comparison of their Average Nucleotide Identity based on Blast (ANIb) [35] and using the Jspecies software [36]. 
A database containing all $m c r-1$ complete plasmids that were available in the National Center for Biotechnology Information (NCBI) database as of 14 February 2017 was created (Table 2). Plasmid type was then determined using the Plasmid finder software, and in-silico analysis of tra genes was performed for the non-conjugative E. coli LH1 strain. The presence of insertion sequence ISApl1 in all plasmids, including those that were present in our created database, was checked. Our four complete mcr-1 plasmids were compared and visualized using CGView software [37]. These plasmids were named pLH30-mcr1, pLH57-mcr1, pLH1-mcr1, and p1RC4-mcr1, and were submitted to Genbank under accession numbers NKYL00000000, NKYM00000000, NKYJ00000000, and NKYK00000000, respectively. An analysis of the genetic environment of the $m c r-1$ gene was performed using blast $X$ on all of the genes around the $m c r-1$ gene in the NCBI. The identity of insertion sequences was confirmed using the ISfinder software [38].

\section{Results}

\subsection{Strain Characteristics}

The colistin MIC of strains harboring the $m c r-1$ gene varied from 3 to $32 \mu \mathrm{g} / \mathrm{mL}$ (Table 1 ). The presence of known chromosomal mechanisms of colistin resistance was found in two E. coli strains due to the PhoQ mutation (E375K) [21]. Regarding three K. pneumoniae strains, resistance was due to mgrB stop in the first strain, a mgrB substitution in the second, and a PmrB mutation (T157P) in the last [22] (Table 1). Different clones were identified with seven different sequence types (STs) in K. pneumoniae strains and 17 different STs in E. coli strains, including six recurrent STs, namely ST 4015, ST 3997, ST 10, ST 93, ST 48, and ST 648 (Table 1, Figure 1). Following the subculture of strains, the loss of the mcr-1 gene was observed in four K. pneumoniae strains after 25 passages. For E. coli strains, only LH30 lost its $m c r-1$ gene after 20 passages. Colistin susceptibility was restored in E. coli LH30 upon the loss of $m c r-1$ gene. However, this was not the case for K. pneumoniae strains, which continued to be colistin resistant after the loss of $m c r-1$ (Table 1).

\subsection{Location of the mor-1 Gene}

The presence of plasmids was demonstrated in all $25 \mathrm{E}$. coli strains, of which 21 carried the $m c r-1$ gene on a conjugative plasmid. For K. pneumoniae strains, only two carried the $m c r-1$ gene on a conjugative plasmid (Table 1). The predominance of IncHI2-type (44.5\%), IncI2-type (40.7\%), and IncP-type (14.8\%) plasmids was observed on the whole strains. The majority of plasmids $(77.8 \%)$ were isolated from humans, including $81.8 \%$ of IncI2-type, $75 \%$ of IncHI2-type, and 75\% of IncP-type plasmids (Table 1). The presence of insertion sequence ISApl1 around the $m c r-1$ gene was found in $56.25 \%$ of strains in the downstream position, and $12.5 \%$ in the downstream and upstream positions. Furthermore, $28.12 \%$ of strains did not have an ISApl1 insertion sequence that was close to the $m c r-1$ gene, and $3.12 \%$ had partial ISApl1 sequences in positions that were downstream and upstream of the mcr-1 gene.

\subsection{Genome Analysis}

\section{Mcr-1 Database}

Fifty-nine $m c r-1$ complete plasmids were retrieved from the NCBI database. Taking into account the $\%$ GC content and the plasmid sizes, our database can be divided into three main groups. The plasmid size was $51.88 \mathrm{~Kb}$ in group 1, $244.81 \mathrm{~Kb}$ in group 2, and 6.39-97.56 Kb in group 3 (Figure 2). Our created $m c r-1$ plasmid database enabled us to see that the closest $m c r-1$ plasmid for pLH30-mcr1 was KU743384, with $99.68 \%$ similarity, while pLH57-mcr1 was KX276657, with $99.11 \%$ similarity, pLH1-mcr1 was KX254341, with 99.91\% similarity, and p1RC4-mcr1 was KU743384, with 99.98\% similarity. All of these plasmids were isolated from E. coli strains. KU743384 was an IncHI2 plasmid that was isolated from E. coli ST68 in Saudi Arabia. KX276657 was an Inc F18:A-:B1 (IncN with Plasmid 
finder software) plasmid isolated from E. coli ST457 in the United States, while KX254341 was an IncHI2 plasmid also isolated from E. coli in China (Table 2). From our $m c r-1$ database, $49 \%$ of plasmids had ISApl1 around the $m c r-1$ gene, of which $75.9 \%$ were in a downstream position and $24.1 \%$ were transposons Tn6330 (Table 2). In eight plasmids, we also found a copy of ISApl1 sequences around the $m c r-1$ gene, as well as in other plasmid locations. For $51 \%$ of plasmids, no ISApl1 sequence was detected in the whole plasmid. The majority of plasmids were isolated from E. coli strains. Plasmid sizes ranged from $33 \mathrm{~Kb}$ to $369 \mathrm{~Kb}$, and GC content varied from $41.84 \%$ to $50.67 \%$. Eight types of plasmids were represented in the database, including $40.7 \%$ IncI2 and $25.4 \%$ IncX4 (Figure 2, Table 2).

\subsection{Sequenced Plasmids}

Concerning the four plasmids that we sequenced, plasmid sizes ranged from $219 \mathrm{~Kb}$ to $248 \mathrm{~Kb}$, and GC\% ranged from 46 to 48 . The plasmids were all IncHI2 type. pLH30-mcr1 and pLH1-mcr1 belonged to ST 3, while p1RC4-mcr1 was ST 1 and pLH57-mor1 had an unknown ST (Table 3). A single copy of the $m c r-1$ gene was found in all of our plasmids. Antibiotic resistance genes other than $m c r-1$ are shown in Table 3. On pLH1-mcr1, the ISApl1 sequence was found to be inserted into the traE gene, leading to a stop codon that inactivated it.

\subsection{Genetic Integration of mor-1 Gene}

In silico analysis confirmed the presence of ISApl1 downstream and upstream of the mcr-1 gene in the pLH30-mcr1. The transposon was surrounded by two genes coding for hypothetical proteins, with one gene coding for a thiol:disulfide interchange protein DsbC to the left and one coding for a $\mathrm{HNH}$ endonuclease to the right of the $m c r-1$ gene. In p1RC4-mcr1, we observed an ISApl1 sequence downstream and upstream in opposite directions, as well as two truncated ORFs and a recombinase close to the mcr-1 gene. In pLH1-mcr1, a classic mcr-1 cassette (ISApl1-mcr-1-ORF) and truncated IS1 insertion sequences were found around the mor-1 transposon. For pLH57-mcr1, we observed a truncated ISApl1 sequence downstream and upstream, and a resolvase near the $m c r-1$ transposon (Figure 3). 
Table 1. Origins and genotypic characteristics of $m c r-1$ strains analysed in this study.

\begin{tabular}{|c|c|c|c|c|c|c|c|c|c|c|}
\hline Strains $m c r-1$ & Country & Origin & $\begin{array}{l}\text { Other Known } \\
\text { Colistin } \\
\text { Mechanisms }\end{array}$ & $\begin{array}{c}\text { MIC } \\
\text { Colistin }\end{array}$ & ST & $\begin{array}{l}\text { Plasmid } \\
\text { Stability }\end{array}$ & Conjugation & Transformation & $\begin{array}{c}\text { Plasmid } \\
\text { Typing }\end{array}$ & ISApl1 \\
\hline Escherichia coli LH1 & Laos & Human & & 6 & 4015 & + & - & - & IncHI2 & downstream \\
\hline E. coli LH30 & Laos & Human & & 6 & 4012 & $-/-(0.25)$ & + & ND & IncHI2 & down+upstream \\
\hline E. coli LH57 & Laos & Human & PhoQ mut (E375K) & 8 & 3997 & + & + & ND & IncHI2 & down ${ }^{*}+$ upstream $*$ \\
\hline E. coli LH121 & Laos & Human & & 16 & 4013 & + & + & ND & IncP & l \\
\hline E. coli LH140 & Laos & Human & PhoQ mut (E375K) & 12 & 3997 & + & + & ND & IncHI2 & downstream \\
\hline E. coli LH257 & Laos & Human & & 12 & 4014 & + & + & ND & IncI2 & down+upstream \\
\hline E. coli P10 & Laos & Pig & & 6 & 4015 & + & - & + & IncP & I \\
\hline E. coli P6 & Laos & Pig & & 6 & 4704 & + & + & ND & IncI2 & / \\
\hline E. coli P17 & Laos & Pig & & 4 & 93 & + & - & + & IncI2 & downstream \\
\hline E. coli $\mathrm{TH} 214$ & Thailand & Human & & 6 & 10 & + & + & ND & IncI2 & downstream \\
\hline E. coli TH99 & Thailand & Human & & 4 & 48 & + & + & ND & IncI2 & / \\
\hline E. coli SE65 & Algeria & Human & & 4 & 405 & + & + & ND & IncP & downstream \\
\hline E. coli 235 & Algeria & Chicken & & 4 & 5758 & + & + & ND & IncHI2 & downstream \\
\hline E. coli SA9 & Algeria & Chicken & & 3 & 48 & + & + & ND & IncHI2 & downstream \\
\hline E. coli SE3 & Algeria & Chicken & & 3 & 48 & + & + & ND & IncHI2 & downstream \\
\hline E. coli $1 \mathrm{R}$ & Traveler & Human & & 4 & 453 & + & - & + & IncP & downstream \\
\hline E. coli 6R & Traveler & Human & & 4 & 648 & + & + & - & IncHI2 & downstream \\
\hline E. coli $44 \mathrm{~A}$ & Traveler & Human & & 4 & 93 & + & + & ND & IncHI2 & / \\
\hline E. coli 85R & Traveler & Human & & 4 & 656 & + & + & ND & IncI2 & down+upstream \\
\hline E. coli 95R & Traveler & Human & & 4 & 10 & + & + & ND & IncI2 & downstream \\
\hline E. coli $96 \mathrm{R}$ & Traveler & Human & & 4 & 10 & + & + & ND & IncI2 & downstream \\
\hline E. coli $117 \mathrm{R}$ & Traveler & Human & & 4 & 648 & + & + & ND & IncHI2 & downstream \\
\hline E. coli $1 \mathrm{RC} 4$ & Traveler & Human & & 4 & 155 & + & + & ND & IncHI2 & down+upstream \\
\hline E. coli $134 \mathrm{R}$ & Traveler & Human & & 3 & 602 & + & + & ND & IncI2 & downstream \\
\hline E. coli $143 \mathrm{R}$ & Traveler & Human & & 3 & 1300 & + & + & ND & IncHI2 & downstream \\
\hline Klebsiella pneumoniae $119 \mathrm{R}$ & Traveler & Human & & 3 & 788 & + & + & ND & IncI2 & downstream \\
\hline K. pneumoniae LH131 & Laos & Human & MgrB (stop) & 32 & 1319 & $-/+(32)$ & - & - & ND & / \\
\hline K. pneumoniae LH17 & Laos & Human & PmrB mut (T157P) & 12 & 37 & $-/+(12)$ & - & - & ND & / \\
\hline K. pneumoniae LH61 & Laos & Human & MgrB (substitution) & 16 & 491 & $-/+(16)$ & + & ND & IncI2 & / \\
\hline K. pneumoniae LH92 & Laos & Human & & 12 & 39 & $-/-(12)$ & - & - & ND & / \\
\hline K. pneumoniae FHM128 & France & Human & & 4 & 1310 & + & - & - & ND & downstream \\
\hline К. pneumoniae FHA60 & France & Human & & 8 & 1307 & + & - & - & ND & downstream \\
\hline
\end{tabular}

* refers to partial sequences, MIC: Minimum Inhibitory Concentration, ST: Sequence Type, ND: Not Determined. 
Table 2. ISApl1 presence, plasmid types and origins of $m c r-1$ plasmids that were included in our database.

\begin{tabular}{|c|c|c|c|c|c|c|c|c|}
\hline $\begin{array}{c}\text { Genbank } \\
\text { Accession } \\
\text { Number }\end{array}$ & $\begin{array}{l}\text { Type of } \\
\text { Plasmid }\end{array}$ & GC\% & Size (bp) & Strain $m c r-1$ & Country & Origin & ISApl1 Presence in Plasmid & Reference \\
\hline СР015913.1 & IncI2 & 43.11 & 65,888 & Escherichia coli & USA & Animal & Not present & [39] \\
\hline СР015977.1 & IncX4 & 41.85 & 33,304 & E. coli & Brazil & Human & Not present & [40] \\
\hline СР016183.1 & IncHI1B & 46.93 & 230,278 & E. coli & Malaysia & Animal & Downstream $m c r-1$ & [41] \\
\hline СР016184.1 & IncHI1B & 47.04 & 235,403 & E. coli & Malaysia & Animal & Downstream $m c r-1+1$ other copy & [41] \\
\hline СР016185.1 & IncI2 & 42.48 & 61,735 & E. coli & Malaysia & Animal & Not present & [41] \\
\hline СР016186.1 & IncI2 & 42.25 & 60,218 & E. coli & Malaysia & Environment & Not present & [41] \\
\hline СР016187.1 & IncI2 & 42.35 & 60,950 & E. coli & Malaysia & Animal & Not present & [41] \\
\hline СР016405.1 & IncI2 & 42.65 & 63,329 & E. coli & USA & Animal & Not present & [42] \\
\hline СР016550.1 & IncX4 & 42.5 & 49,695 & E. coli & Netherlands & Human & Not present & [39] \\
\hline СР017246.1 & IncX4 & 42.48 & 34,992 & E. coli & Brazil & Animal & Not present & [43] \\
\hline СР017632.1 & IncN & 47.4 & 369,298 & E. coli & China & Human & Tn6330 + 2 other copies & [44] \\
\hline СР018106.1 & IncI2 & 42.82 & 64,467 & E. coli & Germany & Human & Downstream mcr-1 & [45] \\
\hline СР018112.1 & IncI2 & 42.82 & 64,467 & E. coli & USA & Human & Downstream $m c r-1$ & [45] \\
\hline СР018118.1 & IncI2 & 42.82 & 64,467 & E. coli & USA & Human & Downstream $m c r-1$ & [45] \\
\hline СР018124.1 & IncI2 & 42.8 & 65,539 & E. coli & USA & Human & Downstream $m c r-1+1$ other copy & [45] \\
\hline СР018773.1 & IncX4 & 41.84 & 33,305 & E. coli & USA & Human & Not present & [46] \\
\hline KP347127.1 & IncI2 & 43 & 64,015 & E. coli & China & Animal & Downstream mcr-1 & [6] \\
\hline KU341381.1 & IncHI2 & 46.53 & 251,493 & E. coli & China & Animal & Downstream $m c r-1$ & [6] \\
\hline KU353730.1 & IncFII & 50.67 & 79,798 & E. coli & Belgium & Animal & Not present & [47] \\
\hline KU647721.2 & IncX4 & 45.95 & 48,350 & E. coli & Unknown & Animal & Not present & [48] \\
\hline KU743383.1 & IncX4 & 41.85 & 33,311 & E. coli & Estonia & Animal & Not present & [49] \\
\hline KU743384.1 & IncHI2 & 46.21 & 240,367 & E. coli & Saudi Arabia & Human & Tn $6330+1$ other copy & [50] \\
\hline KU761326.1 & IncI2 & 42.65 & 64,964 & E. coli & China & Human & Not present & [51] \\
\hline KU761327.1 & IncX4 & 41.84 & 33,287 & Klebsiella pneumoniae & China & Human & Not present & [51] \\
\hline KU870627.1 & IncI2 & 42.46 & 62,219 & E. coli & South Africa & Animal & Downstream $m c r-1$ & [52] \\
\hline KU922754.1 & IncI2 & 42.3 & 57,059 & Kluyvera ascorbata & China & Environment & Not present & [53] \\
\hline KU934209.1 & IncI2 & 42.26 & 65,419 & Salmonella enterica & China & Animal & Downstream $m c r-1$ & [54] \\
\hline KU994859.1 & IncFII & 49.34 & 91,041 & E. coli & Belgium & Animal & Downstream $m c r-1+1$ other partial copy & [55] \\
\hline KX013538.1 & IncI2 & 42.43 & 61,228 & E. coli & United Arab Emirates & Human & Downstream $m c r-1$ & [50] \\
\hline KX013539.1 & IncI2 & 42.69 & 62,661 & E. coli & Bahrain & Human & Not present & [50] \\
\hline KX013540.1 & IncI2 & 42.49 & 64,942 & E. coli & Bahrain & Human & Not present & [50] \\
\hline KX032519.1 & IncI2 & 42.63 & 61,177 & E. coli & South Africa & Human & Downstream $m c r-1$ & [56] \\
\hline KX032520.1 & IncX4 & 41.9 & 31,808 & E. coli & South Africa & Human & Not present & [56] \\
\hline KX034083.1 & IncI2 & 42.51 & 67,134 & E. coli & China & Animal & Downstream $m c r-1$ & [57] \\
\hline KX084392.1 & IncX4 & 41.85 & 33,298 & E. coli & China & Animal & Not present & [58] \\
\hline KX084393.1 & IncI2 & 42.64 & 63,656 & E. coli & China & Animal & Not present & [58] \\
\hline KX084394.1 & IncHI2 & 46.13 & 243,572 & E. coli & China & Animal & $\operatorname{Tn} 6330$ & [58] \\
\hline KX129782.1 & IncHI2 & 46.7 & 247,885 & E. coli & Italy & Food & Tn6330 & [59] \\
\hline
\end{tabular}


Table 2. Cont

\begin{tabular}{|c|c|c|c|c|c|c|c|c|}
\hline $\begin{array}{c}\text { Genbank } \\
\text { Accession } \\
\text { Number }\end{array}$ & $\begin{array}{l}\text { Type of } \\
\text { Plasmid }\end{array}$ & GC $\%$ & Size (bp) & Strain $m c r-1$ & Country & Origin & ISApl1 Presence in Plasmid & Reference \\
\hline KX129783.1 & IncX4 & 42.27 & 34,640 & E. coli & Switzerland & Environment & Not present & [59] \\
\hline KX129784.1 & IncHI1B & 46.48 & 209,401 & E. coli & Thailand & Food & Not present & [59] \\
\hline KX236309.1 & IncX4 & 41.85 & 33,303 & K. pneumoniae & Italy & Human & Not present & [60] \\
\hline KX254341.1 & IncHI2 & 46.64 & 267,486 & E. coli & China & Animal & Not present & [58] \\
\hline KX254342.1 & IncI2 & 42.64 & 63,656 & E. coli & China & Animal & Downstream $m c r-1$ & [58] \\
\hline KX254343.1 & IncX4 & 41.84 & 33,307 & E. coli & China & Animal & Not present & [58] \\
\hline KX257480 & IncFII & 48.01 & 54,502 & S. enterica & Unknown & Animal & Incomplete downstream $m c r-1$ & [61] \\
\hline KX257481 & IncFII & 47.99 & 54,670 & S. enterica & Unknown & Animal & Incomplete downstream $m c r-1$ & [61] \\
\hline KX257482 & IncFII & 48.02 & 54,494 & S. enterica & Unknown & Animal & Not present & [61] \\
\hline KX276657.1 & IncN & 47.99 & 225,069 & E. coli & USA & Human & Downstream $m c r-1+1$ other copy & [62] \\
\hline KX377410.1 & IncFIB & 46.94 & 57,278 & K. pneumoniae & China & Environment & Downstream $m c r-1+1$ other copy & [63] \\
\hline KX447768.1 & IncX4 & 41.84 & 33,395 & E. coli & USA & Human & Not present & [64] \\
\hline KX505142.1 & IncI2 & 42.64 & 65,203 & Cronobacter sakazakii & China & Animal & Downstream $m c r-1$ & [31] \\
\hline KX518745.1 & IncY & 47.46 & 97,559 & E. coli & China & Animal & $\operatorname{Tn} 6630$ & [65] \\
\hline KX528699.1 & IncFIB & 46.99 & 15,998 & E. coli & Vietnam & Animal & Downstream $m c r-1+1$ other copy & [66] \\
\hline KX570748.1 & IncX4 & 41.96 & 32,751 & E. coli & China & Animal & Not present & [67] \\
\hline KX772391.1 & IncFIB & 49.97 & 179,444 & E. coli & China & Human & Tn6330 & [68] \\
\hline KX772777.1 & IncX4 & 41.84 & 33,309 & E. coli & China & Human & Not present & [69] \\
\hline KX772778.1 & IncI2 & 42.47 & 65,375 & E. coli & China & Human & Not present & [69] \\
\hline KX880944.1 & IncY & 47.75 & 97,386 & E. coli & China & Animal & Tn6630 & [70] \\
\hline LT174530 & IncI2 & 42.5 & 61,826 & Shigella sonnei & Vietnam & Human & Downstream $m c r-1$ & [71] \\
\hline
\end{tabular}




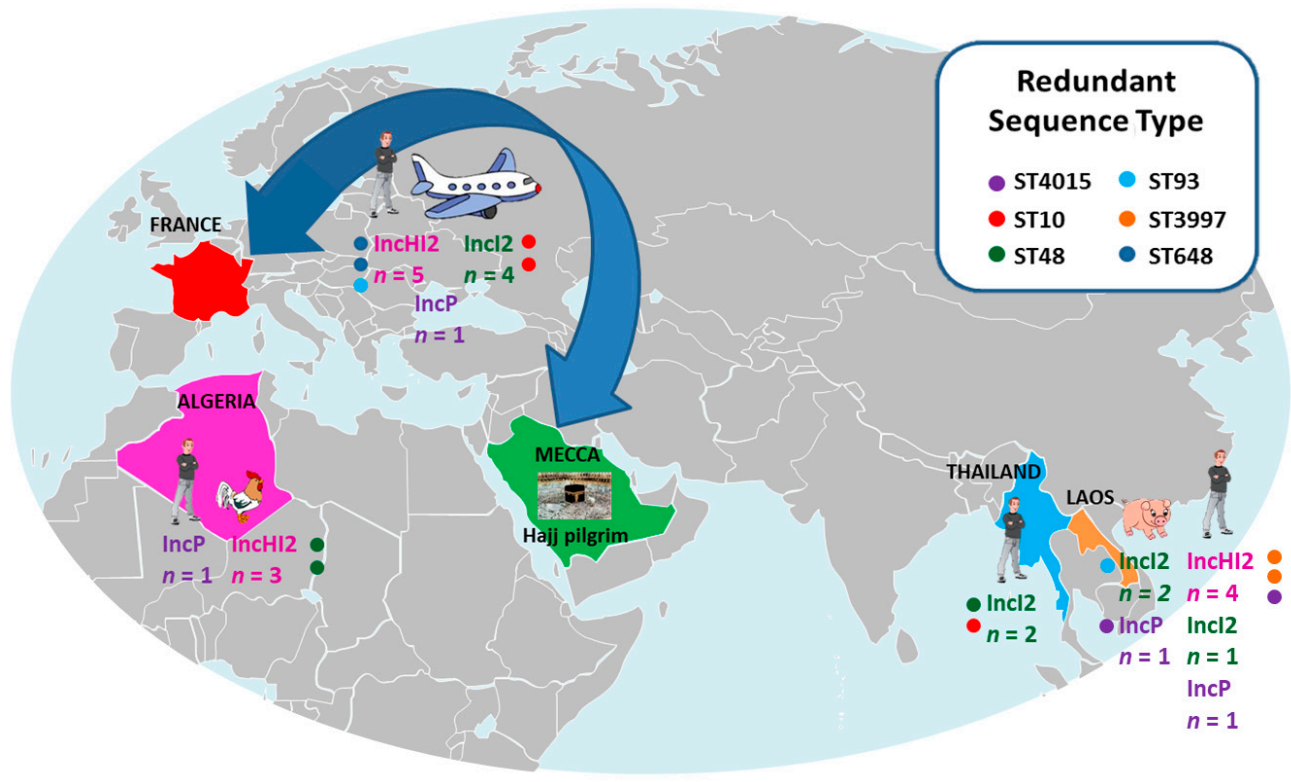

Figure 1. Origins and plasmid type of $m c r-1$ strains collected in our study.

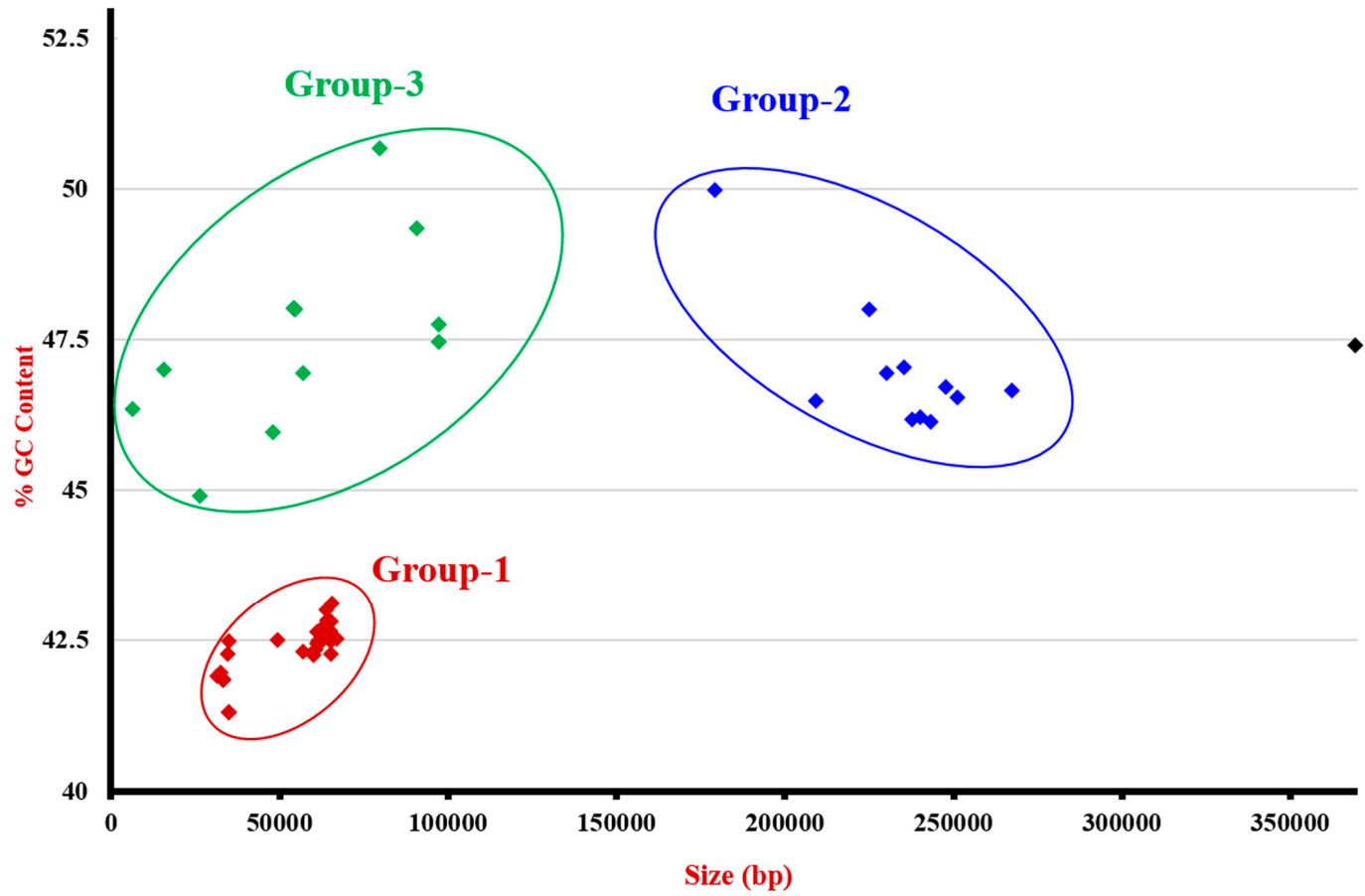

Figure 2. Diversity of plasmids carrying the $m c r-1$ gene. All of these plasmids were retrieved from the NCBI database and were plotted according to their GC\% and size. Group-1 includes plasmids from E. coli, C. sakazaki, K. pneumoniae, K. ascorbata, S. enterica, and S. sonnei. The average size and \%GC were estimated as $51.88-\mathrm{Kb}$ and $41.32 \mathrm{GC} \%$, respectively. The identified incompatibility plasmid types were IncI2, IncX4. Group-2 includes plasmids from E. coli only. The average size and \%GC content were $244.81-\mathrm{Kb}$ and $47.02 \% \mathrm{GC}$, respectively. The incompatibility plasmid types of this group were: IncHI1B, IncHI2, IncFIB, IncN. Group-3 includes plasmids from E. coli, K. pneumoniae, and S. enterica. Their sizes varied from 6.39 to $97.56-\mathrm{Kb}$ and the GC\% content from 44.89 to $50.57 \%$. The incompatibility plasmid types of this group were IncFII, IncX4, IncFIB, IncY. A single plasmid from E. coli (in black) with size of $369.30-\mathrm{Kb}, 47.4 \%$ of GC content, and belonging to the IncN plasmid type was identified. 
Table 3. In silico analysis of the four sequences of $m c r-1$ plasm.

\begin{tabular}{|c|c|c|c|c|c|c|c|}
\hline mcr-1 Plasmid & $\begin{array}{l}\text { Type of } \\
\text { Plasmid }\end{array}$ & pMLST & GC\% & Size (bp) & Resistance Genes & ISApl1 Presence in Plasmid & $\begin{array}{c}\text { Genbank Accession } \\
\text { Number }\end{array}$ \\
\hline pLH30-mcr1 & IncHI2 & ST 3 & 45.91 & 223,898 & $\begin{array}{l}\text { mcr-1, bla } \mathrm{TEM}-217, \text { cmlA1, floR, aph3-Ia, } \\
\text { aadA2, sulIII, dfrA17, mefB }\end{array}$ & $\begin{array}{c}2 \text { sequences: } \\
1 \text { downstream and } \\
1 \text { upstream } m c r-1 \text { gene }\end{array}$ & NKYL00000000 \\
\hline pLH57-mcr1 & IncHI2 & Unknown ST & 48.00 & 218,800 & $\begin{array}{l}\text { mcr-1, bla } a_{\mathrm{TEM}-217}, \text { tet } A, \text { tetR, strA, strB, } \\
\text { aph3"-Ib, aph6-Id, sulII, dfrA14 }\end{array}$ & $\begin{array}{l}2 \text { truncated sequences: } \\
1 \text { downstream and } \\
1 \text { upstream } m c r-1 \text { gene }\end{array}$ & NKYM00000000 \\
\hline pLH1-mcr1 & IncHI2 & ST 3 & 46.38 & 248,201 & $\begin{array}{c}\text { mcr-1, bla } a_{\mathrm{TEM}-217}, \text { tet } A, \text { tetR, aad } A 2, \text { oq } x A, \\
\text { oq } x B g b, \text { sull, sulIII, dfrA12 }\end{array}$ & $\begin{array}{c}2 \text { sequences: } \\
1 \text { downstream } m c r-1 \text { gene and } \\
1 \text { inside } t r a E \text { gene }\end{array}$ & NKYJ00000000 \\
\hline p1RC4-mcr1 & IncHI2 & ST 4 & 46.22 & 239,098 & $\begin{array}{c}\text { mcr-1, bla } a_{\mathrm{TEM}-217} \text {, tet } A, \text { tet } R, \text { floR, } \\
\text { aph3-Ia, aph3-Ib, aadA1, strA, sulIII, dfrA14 }\end{array}$ & $\begin{array}{c}2 \text { sequences: } \\
1 \text { downstream and } \\
1 \text { upstream } m c r-1 \text { gene }\end{array}$ & NKYK00000000 \\
\hline
\end{tabular}




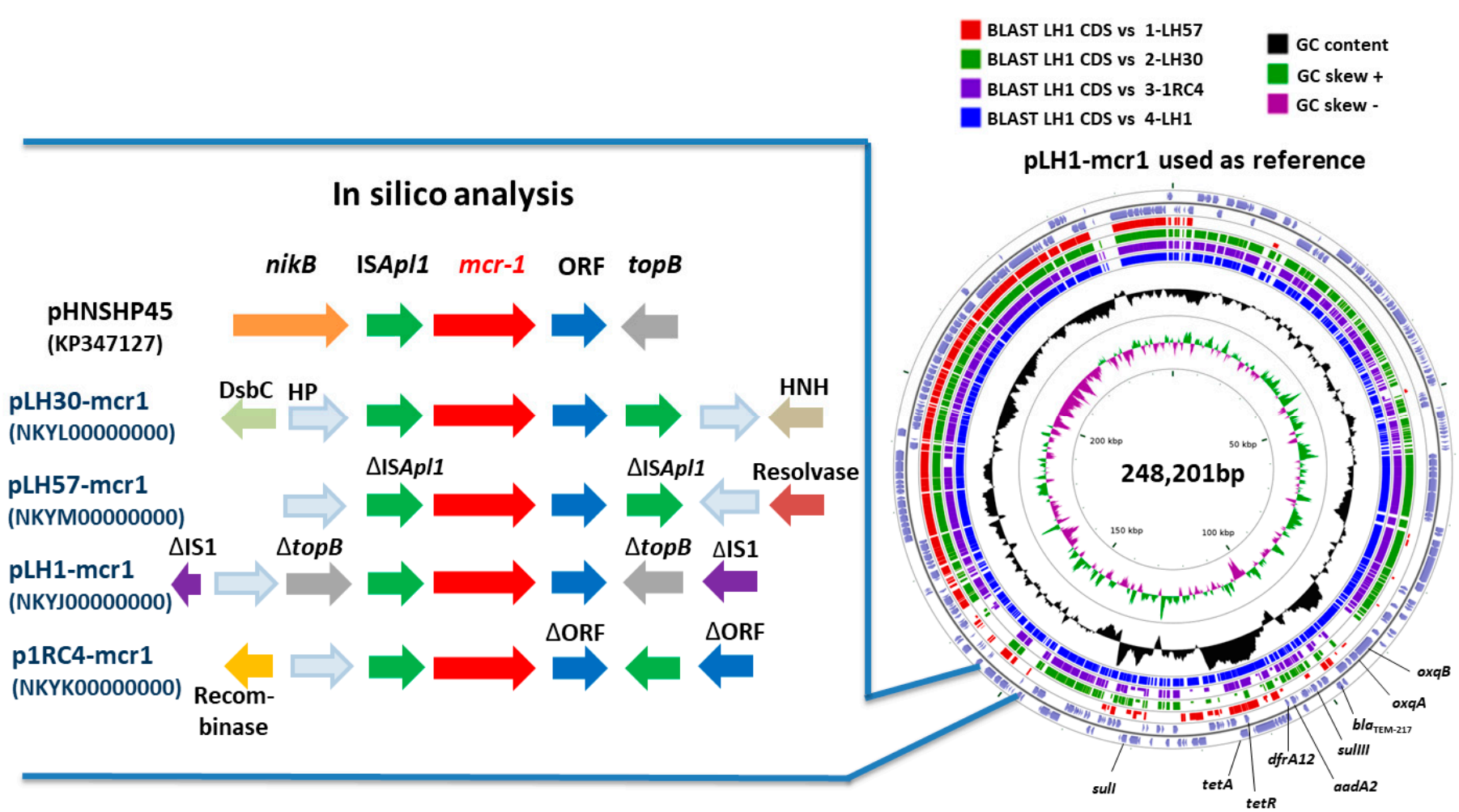

Figure 3. Genetic environment of the mcr-1 gene in plasmids: pHNSHP45 (KP347127), pLH30-mcr1 (NKYL00000000), pLH57-mcr1 (NKYM00000000), pLH1-mcr1 (NKYJ00000000), and p1RC4-mcr1 (NKYK00000000). Comparison of the four complete mcr-1 plasmids was performed using blastP with CGview software. nickB refers to Nickel B, topB: topoisomerase B, DsbC: Thiol:disulfide interchange protein DsbC, HP: Hypothetical protein, HNH: HNH endonuclease, IS: Insertion sequence. 


\section{Discussion}

The presence of the $m c r-1$ gene led to a relatively low colistin resistance between 2 and $8 \mu \mathrm{g} / \mathrm{mL}$ in isolates. For some strains, the high colistin MIC observed was due to the presence of additional chromosomal mechanisms of resistance (Table 1). Interestingly, we observed that K. pneumoniae strains with high MIC appeared to lose $m c r-1$ plasmids more easily. For these strains, the loss of the $m c r-1$ gene did not lead to a change in their MIC, and they remained resistant to colistin. Hence, the $m c r-1$ gene was not essential to their survival. In our study, the clonal dissemination of E. coli carrying the mcr-1 gene was diverse, with 17 different STs, although some STs appeared several times. These STs were not related to a common sample origin or to a specific country. The presence of the same ST 4015 in two strains that were isolated in a same village from a human and a pig was described as a possible case of animal/human transmission [21]. The presence of ST 648 in two different travellers and ST 3997 in two villagers would appear to be a case of inter-human transmission. ST 48 and specially ST 10 were widespread STs, and have often been described for $m c r-1$ in the literature [7]. Strains could carry different types of plasmids encoding the $m c r-1$ gene $[12,64]$. Hence, the spread of the $m c r-1$ gene could be unrelated to a specific clonal population.

Thus far, eight plasmid types carrying the $m c r-1$ gene have been described around the world [12]. Our study confirmed this by observing only three plasmid types that were randomly present in different countries, as well as in humans and animals. Mcr-1 database analysis confirms the global propagation of such plasmids, especially the smallest IncI2- and IncX4-type plasmids. The genetic environment of the $m c r-1$ gene was first described by the ISApl1-mcr-1-ORFcassette [6]. In this study, this combination was commonly found. The transposon Tn6330 (ISApl1-mcr-1-ORF- ISApl1), described as being responsible for $m c r-1$ gene transfer $[15,58]$, was found in few strains, including E. coli LH30. This could be the reason for early $m c r-1$ gene loss in this strain. Interestingly, the presence of the ISApl1sequence was not always around the mor-1 gene [13,45]. In pLH1-mcr1, ISApl1 was found downstream of the $m c r-1$ gene and inside the traE gene. This insertion sequence disrupts the traE gene, leading to the inactivation of this gene and affecting the capacity of the bacteria to transfer the plasmid through conjugation. This insertion site into the traE gene has already been described in such IncK2 plasmids in Switzerland, and has been associated with a lower frequency of conjugation [72,73].

A certain percentage of plasmids did not display an ISApl1 sequence around the $m c r-1$ gene $[16,74]$. This led to two hypotheses: the $m c r-1$ gene lost ISApl1 and stabilized it into a plasmid, or the $m c r-1$ gene was transferred by other insertion sequences. The presence of ISApl1 in other places in the plasmid supports the first hypothesis and confirmed its original role in $m c r-1$ gene transfer. Furthermore, in the composite transposon Tn2706, which is composed of 2 IS30, the loss of one IS was described as being favourable for the stabilization of genes in the new location [75].

In a recent study, ISApl1 was described as being a highly active IS and being able to transpose at a very high frequency in different nonspecific insertion sites [45]. For pLH1-mcr1, transposition was performed into a hotspot in the vicinity of a truncated IS1 insertion sequence. Moreover, a recombinase and a resolvase were found near the $m c r-1$ transposon of p1RC4-mcr1 and pLH57-mcr1. Resolvase or recombinase are nucleases involved in DNA recombination. Their presence was a sign of recombination hotspots that were favourable to a transposon insertion. For pLH30-mcr1, an HNH endonuclease was present near the $m c r-1$ transposon. Homing endonucleases were involved with lateral transfer as an intron to a homologous allele [76]. This could also be interpreted as a sign of a variable region suitable for insertion sequences.

\section{Conclusions}

Here, we show that worldwide dissemination of $m c r-1$ encoding gene was due to the spread of a transposon, which can be found in different plasmid types and/or bacterial chromosomes. Even if some STs were redundant, dissemination was not due to a specific clonal population or to a specific plasmid type. Initially, the transfer of the mcr-1 gene was due to Tn6330. Then, in order to stabilize in a new location, the transposon lost one or both ISApl1 sequences. It is likely that the evolution 
of the genetic environment of the $m c r-1$ gene could lead to a diversity of insertion sequences of the $m c r-1$ gene. This could raise the risk of a possible translocation into the chromosome. An emergence of a preponderant clone and the rapid dissemination of the $m c r-1$ gene in Gram-negative bacteria are possible. Hence, we consider that it is essential to continue to survey resistance to colistin in those strains.

Acknowledgments: The authors thank American Journal Experts for reading the manuscript.

Author Contributions: L.H. wrote the manuscript, performed experiments, and analysed the data. T.R. created the $m c r-1$ database and helped draft the manuscript. Y.Z. and J.L. performed the sequencing and helped draft the manuscript. S.D. participated in the bioinformatics analysis and helped draft the manuscript. J.M.R. conceived the study, participated in its design and coordination, and helped draft the manuscript. All authors read and approved the final manuscript.

Conflicts of Interest: The authors declare no conflict of interest.

\section{References}

1. Grundmann, H.; Glasner, C.; Albiger, B.; Aanensen, D.M.; Tomlinson, C.T.; Andrasević, A.T.; Cantón, R.; Carmeli, Y.; Friedrich, A.W.; Giske, C.G.; et al. Occurrence of carbapenemase-producing Klebsiella pneumoniae and Escherichia coli in the European survey of carbapenemase-producing Enterobacteriaceae (EuSCAPE): A prospective, multinational study. Lancet Infect. Dis. 2017, 17, 153-163. [CrossRef]

2. Biswas, S.; Brunel, J.-M.; Dubus, J.-C.; Reynaud-Gaubert, M.; Rolain, J.-M. Colistin: An update on the antibiotic of the 21st century. Expert Rev. Anti. Infect. Ther. 2012, 10, 917-934. [CrossRef] [PubMed]

3. Stein, A.; Raoult, D. Colistin: An Antimicrobial for the 21st Century? Clin. Infect. Dis. 2002, 35, 901-902. [CrossRef] [PubMed]

4. Jeannot, K.; Bolard, A.; Plésiat, P. Resistance to polymyxins in Gram-negative organisms. Int. J. Antimicrob. Agents 2017, 49, 526-535. [CrossRef] [PubMed]

5. Baron, S.; Hadjadj, L.; Rolain, J.M.; Olaitan, A.O. Molecular mechanisms of polymyxin resistance: Knowns and unknowns. Int. J. Antimicrob. Agents 2016. [CrossRef] [PubMed]

6. Liu, Y.-Y.; Wang, Y.; Walsh, T.R.; Yi, L.-X.; Zhang, R.; Spencer, J.; Doi, Y.; Tian, G.; Dong, B.; Huang, X.; et al. Emergence of plasmid-mediated colistin resistance mechanism MCR-1 in animals and human beings in China: A microbiological and molecular biological study. Lancet Infect. Dis. 2016, 16, 161-168. [CrossRef]

7. Yang, Y.-Q.; Li, Y.-X.; Song, T.; Yang, Y.-X.; Jiang, W.; Zhang, A.-Y.; Guo, X.-Y.; Liu, B.-H.; Wang, Y.-X.; Lei, C.-W.; et al. Colistin Resistance Gene mcr-1 and Its Variant in Escherichia coli Isolates from Chickens in China. Antimicrob. Agents Chemother. 2017, 61, e01204-16. [CrossRef] [PubMed]

8. Xavier, B.B.; Lammens, C.; Ruhal, R.; Kumar-Singh, S.; Butaye, P.; Goossens, H.; Malhotra-Kumar, S. Identification of a novel plasmid-mediated colistin-resistance gene, mor-2, in Escherichia coli, Belgium, June 2016. Eurosurveillance 2016, 21, 30280. [CrossRef] [PubMed]

9. Yin, W.; Li, H.; Shen, Y.; Liu, Z.; Wang, S.; Shen, Z.; Zhang, R.; Walsh, T.R.; Shen, J.; Wang, Y. Novel Plasmid-Mediated Colistin Resistance Gene mor-3 in Escherichia coli. mBio 2017, 8, e00543-17. [CrossRef] [PubMed]

10. Carattoli, A.; Villa, L.; Feudi, C.; Curcio, L.; Orsini, S.; Luppi, A.; Pezzotti, G.; Magistrali, C.F. Novel plasmid-mediated colistin resistance mcr-4 gene in Salmonella and Escherichia coli, Italy 2013, Spain and Belgium, 2015 to 2016. Euro Surveill. 2017, 22, 30589. [CrossRef] [PubMed]

11. Borowiak, M.; Fischer, J.; Hammerl, J.A.; Hendriksen, R.S.; Szabo, I.; Malorny, B. Identification of a novel transposon-associated phosphoethanolamine transferase gene, $m c r-5$, conferring colistin resistance in d-tartrate fermenting Salmonella enterica subsp. enterica serovar Paratyphi B. J. Antimicrob. Chemother. 2017. [CrossRef] [PubMed]

12. Sun, J.; Fang, L.-X.; Wu, Z.; Deng, H.; Yang, R.-S.; Li, X.-P.; Li, S.-M.; Liao, X.-P.; Feng, Y.; Liu, Y.-H. Genetic Analysis of the IncX4 Plasmids: Implications for a Unique Pattern in the mcr-1 Acquisition. Sci. Rep. 2017, 7 , 424. [CrossRef] [PubMed]

13. Wang, Q.; Sun, J.; Li, J.; Ding, Y.; Li, X.-P.; Lin, J.; Hassan, B.; Feng, Y. Expanding landscapes of the diversified mcr-1-bearing plasmid reservoirs. Microbiome 2017, 5, 70. [CrossRef] [PubMed] 
14. Tegetmeyer, H.E.; Jones, S.C.P.; Langford, P.R.; Baltes, N. ISApl1, a novel insertion element of Actinobacillus pleuropneumoniae, prevents ApxIV-based serological detection of serotype 7 strain AP76. Vet. Microbiol. 2008, 128, 342-353. [CrossRef] [PubMed]

15. Poirel, L.; Kieffer, N.; Nordmann, P. In-vitro study of IS Apl1 -mediated mobilization of the colistin resistance gene mor-1. Antimicrob. Agents Chemother. 2017. [CrossRef] [PubMed]

16. Snesrud, E.; He, S.; Chandler, M.; Dekker, J.P.; Hickman, A.B.; McGann, P.; Dyda, F. A Model for Transposition of the Colistin Resistance Gene mor-1 by IS Apl1. Antimicrob. Agents Chemother. 2016, 60, 6973-6976. [CrossRef] [PubMed]

17. Berrazeg, M.; Hadjadj, L.; Ayad, A.; Drissi, M.; Rolain, J.M. First detected human case in Algeria of $m c r-1$ plasmid-mediated colistin resistance in a 2011 Escherichia coli isolate. Antimicrob. Agents Chemother. 2016, 60, 6996-6997. [CrossRef] [PubMed]

18. Olaitan, A.O.; Chabou, S.; Okdah, L.; Morand, S.; Rolain, J.-M. Dissemination of the mcr-1 colistin resistance gene. Lancet Infect. Dis. 2016, 16, 147. [CrossRef]

19. Rolain, J.-M.; Kempf, M.; Leangapichart, T.; Chabou, S.; Olaitan, A.O.; Le Page, S.; Morand, S.; Raoult, D. Plasmid-Mediated mcr-1 Gene in Colistin-Resistant Clinical Isolates of Klebsiella pneumoniae in France and Laos. Antimicrob. Agents Chemother. 2016, 60, 6994-6995. [CrossRef] [PubMed]

20. Leangapichart, T.; Gautret, P.; Brouqui, P.; Memish, Z.A.; Raoult, D.; Rolain, J.-M. Correction for Leangapichart et al., Acquisition of mcr-1 Plasmid-Mediated Colistin Resistance in Escherichia coli and Klebsiella pneumoniae during Hajj 2013 and 2014. Antimicrob. Agents Chemother. 2016, 60, 7537. [CrossRef] [PubMed]

21. Olaitan, A.O.; Thongmalayvong, B.; Akkhavong, K.; Somphavong, S.; Paboriboune, P.; Khounsy, S.; Morand, S.; Rolain, J.-M. Clonal transmission of a colistin-resistant Escherichia coli from a domesticated pig to a human in Laos: Table 1. J. Antimicrob. Chemother. 2015, 47, dkv252. [CrossRef] [PubMed]

22. Olaitan, A.O.; Diene, S.M.; Kempf, M.; Berrazeg, M.; Bakour, S.; Gupta, S.K.; Thongmalayvong, B.; Akkhavong, K.; Somphavong, S.; Paboriboune, P.; et al. Worldwide emergence of colistin resistance in Klebsiella pneumoniae from healthy humans and patients in Lao PDR, Thailand, Israel, Nigeria and France owing to inactivation of the PhoP/PhoQ regulator mgrB: An epidemiological and molecular study. Int. J. Antimicrob. Agents 2014, 44, 500-507. [CrossRef] [PubMed]

23. EUCAST. European Committee on Antimicrobial Susceptibility Testing Breakpoint tables for interpretation of MICs and zone diameters European Committee on Antimicrobial Susceptibility Testing Breakpoint tables for interpretation of MICs and zone diameters. Available online: http:/ / www.eucast.org/fileadmin/src/ media/PDFs/EUCAST_files/Breakpoint_tables/v_50_Breakpoint_Table_01.pdf (accessed on 4 January 2017).

24. Chabou, S.; Leangapichart, T.; Okdah, L.; Le Page, S.; Hadjadj, L.; Rolain, J.M. Real-time quantitative PCR assay with Taqman probe for rapid detection of MCR-1 plasmid-mediated colistin resistance. New Microbes New Infect. 2016, 13, 71-74. [CrossRef] [PubMed]

25. Escherichia coli_Enterobase. Available online: http://mlst.warwick.ac.uk/mlst/dbs/Ecoli (accessed on 20 January 2017).

26. Klebsiella sequence typing. Available online: http:// bigsdb.web.pasteur.fr/klebsiella (accessed on 20 January 2017).

27. Sennati, S.; Di Pilato, V.; Riccobono, E.; Di Maggio, T.; Villagran, A.L.; Pallecchi, L.; Bartoloni, A.; Rossolini, G.M.; Giani, T. Citrobacter braakii carrying plasmid-borne $m c r-1$ colistin resistance gene from ready-to-eat food from a market in the Chaco region of Bolivia. J. Antimicrob. Chemother. 2017, 72, 2127-2129. [CrossRef] [PubMed]

28. Bachiri, T.; Bakour, S.; Lalaoui, R.; Belkebla, N.; Allouache, M.; Rolain, J.M.; Touati, A. Occurrence of Carbapenemase-Producing Enterobacteriaceae Isolates in the Wildlife: First Report of OXA-48 in Wild Boars in Algeria. Microb. Drug Resist. 2017. [CrossRef] [PubMed]

29. Carattoli, A.; Bertini, A.; Villa, L.; Falbo, V.; Hopkins, K.L.; Threlfall, E.J. Identification of plasmids by PCR-based replicon typing. J. Microbiol. Methods 2005, 63, 219-228. [CrossRef] [PubMed]

30. Chen, L.; Chavda, K.D.; Al Laham, N.; Melano, R.G.; Jacobs, M.R.; Bonomo, R.A.; Kreiswirth, B.N. Complete Nucleotide Sequence of a blaKPC-Harboring IncI2 Plasmid and Its Dissemination in New Jersey and New York Hospitals. Antimicrob. Agents Chemother. 2013, 57, 5019-5025. [CrossRef] [PubMed] 
31. Liu, B.-T.; Song, F.-J.; Zou, M.; Hao, Z.-H.; Shan, H. Emergence of Colistin Resistance Gene mcr-1 in Cronobacter sakazakii Producing NDM-9 and in Escherichia coli from the Same Animal. Antimicrob. Agents Chemother. 2017, 61. [CrossRef] [PubMed]

32. Aziz, R.K.; Bartels, D.; Best, A.A.; DeJongh, M.; Disz, T.; Edwards, R.A.; Formsma, K.; Gerdes, S.; Glass, E.M.; Kubal, M.; et al. The RAST Server: Rapid Annotations using Subsystems Technology. BMC Genom. 2008, 9, 75. [CrossRef] [PubMed]

33. Gupta, S.K.; Padmanabhan, B.R.; Diene, S.M.; Lopez-Rojas, R.; Kempf, M.; Landraud, L.; Rolain, J.-M. ARG-ANNOT, a New Bioinformatic Tool To Discover Antibiotic Resistance Genes in Bacterial Genomes. Antimicrob. Agents Chemother. 2014, 58, 212-220. [CrossRef] [PubMed]

34. Carattoli, A.; Zankari, E.; Garcia-Fernandez, A.; Voldby Larsen, M.; Lund, O.; Villa, L.; Moller Aarestrup, F.; Hasman, H. In Silico Detection and Typing of Plasmids using PlasmidFinder and Plasmid Multilocus Sequence Typing. Antimicrob. Agents Chemother. 2014, 58, 3895-3903. [CrossRef] [PubMed]

35. Johnson, M.; Zaretskaya, I.; Raytselis, Y.; Merezhuk, Y.; McGinnis, S.; Madden, T.L. NCBI BLAST: A better web interface. Nucleic Acids Res. 2008, 36, W5-W9. [CrossRef] [PubMed]

36. Richter, M.; Rossello-Mora, R.; Oliver Glackner, F.; Peplies, J. JSpeciesWS: A web server for prokaryotic species circumscription based on pairwise genome comparison. Bioinformatics 2016, 32, 929-931. [CrossRef] [PubMed]

37. Grant, J.R.; Arantes, A.S.; Stothard, P. Comparing thousands of circular genomes using the CGView Comparison Tool. BMC Genom. 2012, 13, 202. [CrossRef] [PubMed]

38. Siguier, P.; Perochon, J.; Lestrade, L.; Mahillon, J.; Chandler, M. ISfinder: The reference centre for bacterial insertion sequences. Nucleic Acids Res. 2006, 34, D32-D36. [CrossRef] [PubMed]

39. Meinersmann, R.J.; Ladely, S.R.; Plumblee, J.R.; Hall, M.C.; Simpson, S.A.; Ballard, L.L.; Scheffler, B.E.; Genzlinger, L.L.; Cook, K.L. Complete Genome Sequence of a Colistin Resistance mcr-1 Gene-Bearing Escherichia coli Strain from the United States. Genome Announc. 2016. [CrossRef]

40. Fernandes, M.R.; McCulloch, J.A.; Vianello, M.A.; Moura, Q.; Pérez-Chaparro, P.J.; Esposito, F.; Sartori, L.; Dropa, M.; Matté, M.H.; Lira, D.P.A.; et al. First Report of the Globally Disseminated IncX4 Plasmid Carrying the $m c r-1$ Gene in a Colistin-Resistant Escherichia coli Sequence Type 101 Isolate from a Human Infection in Brazil. Antimicrob. Agents Chemother. 2016, 60, 6415-6417. [CrossRef] [PubMed]

41. Yu, C.Y.; Ang, G.Y.; Chong, T.-M.; Chin, P.S.; Ngeow, Y.F.; Yin, W.-F.; Chan, K.-G. Complete genome sequencing revealed novel genetic contexts of the mor-1 gene in Escherichia coli strains. J. Antimicrob. Chemother. 2017, 72, 1253-1255. [CrossRef] [PubMed]

42. Meinersmann, R.J.; Ladely, S.R.; Bono, J.L.; Plumblee, J.R.; Hall, M.C.; Genzlinger, L.L.; Cook, K.L. Complete Genome Sequence of a Colistin Resistance Gene ( $m c r-1)$-Bearing Isolate of Escherichia coli from the United States. Genome Announc. 2016, 4, e01283-16. [CrossRef] [PubMed]

43. Sellera, F.P.; Fernandes, M.R.; Carvalho, M.N.; Nascimiento, C.L.; Dutra, G.P.; McCulloch, J.A.; Pérez-Chaparro, P.J.; Sartori, L.; Lincopan, N. Identification of $m c r-1$ in Escherichia coli isolates from footpad lesions in South American penguin. (Unpublished).

44. Bai, L.; Wang, J.; Hurley, D.; Yu, Z.; Wang, L.; Chen, Q.; Li, J.; Li, F.; Fanning, S. Characterisation of two large plasmids containing ESBL genes; a novel disrupted $m c r-1$ gene and a lysogenized phage P-1 like sequence, cultured from a human atypical enteropathogenic Escherichia coli (aEPEC) recovered in China. Unpublished.

45. Snesrud, E.; Ong, A.C.; Corey, B.; Kwak, Y.I.; Clifford, R.; Gleeson, T.; Wood, S.; Whitman, T.J.; Lesho, E.P.; Hinkle, M.; McGann, P. Analysis of Serial Isolates of mcr-1 -Positive Escherichia coli Reveals a Highly Active IS Apl1 Transposon. Antimicrob. Agents Chemother. 2017, 61, e00056-17. [CrossRef] [PubMed]

46. Lindsey, R.L.; Batra, D.; Rowe, L.; Loparev, V.N.; Stripling, D.; Garcia-Toledo, L.; Knipe, K.; Juieng, P.; Sheth, M.; Martin, H.; et al. High-Quality Genome Sequence of an Escherichia coli O157 Strain Carrying an mor-1 Resistance Gene Isolated from a Patient in the United States. Genome Announc. 2017, 5, e01725-16. [CrossRef] [PubMed]

47. Malhotra-Kumar, S.; Xavier, B.B.; Das, A.J.; Lammens, C.; Butaye, P.; Goossens, H. Colistin resistance gene mcr-1 harboured on a multidrug resistant plasmid. Lancet. Infect. Dis. 2016, 16, 283-284. [CrossRef]

48. Yang, R.-S.J.; Sun, J.; Fang, L.-X. Escherichia coli strain CQ02-121 plasmid pCQ02-121, complete sequence. Unpublished. 
49. Brauer, A.; Telling, K.; Laht, M.; Kalmus, P.; Lutsar, I.; Remm, M.; Kisand, V.; Tenson, T. Plasmid with Colistin Resistance Gene $m c r-1$ in Extended-Spectrum- $\beta$-Lactamase-Producing Escherichia coli Strains Isolated from Pig Slurry in Estonia. Antimicrob. Agents Chemother. 2016, 60, 6933-6936. [CrossRef] [PubMed]

50. Sonnevend, Á.; Ghazawi, A.; Alqahtani, M.; Shibl, A.; Jamal, W.; Hashmey, R.; Pal, T. Plasmid-mediated colistin resistance in Escherichia coli from the Arabian Peninsula. Int. J. Infect. Dis. 2016, 50, 85-90. [CrossRef] [PubMed]

51. Li, A.; Yang, Y.; Miao, M.; Chavda, K.D.; Mediavilla, J.R.; Xie, X.; Feng, P.; Tang, Y.-W.; Kreiswirth, B.N.; Chen, L.; Du, H. Complete Sequences of $m c r-1$-Harboring Plasmids from Extended-Spectrum- $\beta$-Lactamaseand Carbapenemase-Producing Enterobacteriaceae. Antimicrob. Agents Chemother. 2016, 60, 4351-4354. [CrossRef] [PubMed]

52. Perreten, V.; Strauss, C.; Collaud, A.; Gerber, D. Colistin Resistance Gene mcr-1 in Avian-Pathogenic Escherichia coli in South Africa. Antimicrob. Agents Chemother. 2016, 60, 4414-4415. [CrossRef] [PubMed]

53. Zhao, F.; Zong, Z. Kluyvera ascorbata carrying the mor-1 colistin resistance gene from hospital sewage. Antimicrob. Agents Chemother. 2016. [CrossRef]

54. Yang, Y.-Q.; Zhang, A.-Y.; Ma, S.-Z.; Kong, L.-H.; Li, Y.-X.; Liu, J.-X.; Davis, M.A.; Guo, X.-Y.; Liu, B.-H.; Lei, C.-W.; Wang, H.-N. Co-occurrence of mcr-1 and ESBL on a single plasmid in Salmonella enterica. J. Antimicrob. Chemother. 2016, 71, 2336-2338. [CrossRef] [PubMed]

55. Xavier, B.B.; Lammens, C.; Butaye, P.; Goossens, H.; Malhotra-Kumar, S. Complete sequence of an IncFII plasmid harbouring the colistin resistance gene $m c r-1$ isolated from Belgian pig farms. J. Antimicrob. Chemother. 2016, 71, 2342-2344. [CrossRef] [PubMed]

56. Poirel, L.; Kieffer, N.; Brink, A.; Coetze, J.; Jayol, A.; Nordmann, P. Genetic Features of MCR-1-Producing Colistin-Resistant Escherichia coli Isolates in South Africa. Antimicrob. Agents Chemother. 2016, 60, 4394-4397. [CrossRef] [PubMed]

57. Sun, J.; Li, X.-P.; Yang, R.-S.; Fang, L.-X.; Huo, W.; Li, S.-M.; Jiang, P.; Liao, X.-P.; Liu, Y.-H. Complete Nucleotide Sequence of an IncI2 Plasmid Coharboring blaCTX-M-55 and mcr-1. Antimicrob. Agents Chemother. 2016, 60, 5014-5017. [CrossRef] [PubMed]

58. Li, R.; Xie, M.; Zhang, J.; Yang, Z.; Liu, L.; Liu, X.; Zheng, Z.; Chan, E.W.-C.; Chen, S. Genetic characterization of $m c r-1$-bearing plasmids to depict molecular mechanisms underlying dissemination of the colistin resistance determinant. J. Antimicrob. Chemother. 2017, 72, 393-401. [CrossRef] [PubMed]

59. Zurfluh, K.; Klumpp, J.; Nüesch-Inderbinen, M.; Stephan, R. Full-Length Nucleotide Sequences of $m c r-1$ -Harboring Plasmids Isolated from Extended-Spectrum- $\beta$-Lactamase-Producing Escherichia coli Isolates of Different Origins. Antimicrob. Agents Chemother. 2016, 60, 5589-5591. [CrossRef] [PubMed]

60. Di Pilato, V.; Arena, F.; Tascini, C.; Cannatelli, A.; Henrici De Angelis, L.; Fortunato, S.; Giani, T.; Menichetti, F.; Rossolini, G.M. mcr-1.2, a New mcr Variant Carried on a Transferable Plasmid from a Colistin-Resistant KPC Carbapenemase-Producing Klebsiella pneumoniae Strain of Sequence Type 512. Antimicrob. Agents Chemother. 2016, 60, 5612-5615. [CrossRef] [PubMed]

61. Liu, J.H.; Yi, L.X.; Wang, J. Distribution of mcr-1 in Salmonella enterica. Unpublished.

62. McGann, P.; Snesrud, E.; Maybank, R.; Corey, B.; Ong, A.C.; Clifford, R.; Hinkle, M.; Whitman, T.; Lesho, E.; Schaecher, K.E. Escherichia coli Harboring $m c r-1$ and $b l a_{\text {CTX-M }}$ on a Novel IncF Plasmid: First Report of mcr-1 in the United States. Antimicrob. Agents Chemother. 2016, 60, 4420-4421. [CrossRef] [PubMed]

63. Zhao, F.; Feng, Y.; Lü, X.; McNally, A.; Zong, Z. IncP Plasmid Carrying Colistin Resistance Gene mcr-1 in Klebsiella pneumoniae from Hospital Sewage. Antimicrob. Agents Chemother. 2017, 61. [CrossRef] [PubMed]

64. Mediavilla, J.R.; Patrawalla, A.; Chen, L.; Chavda, K.D.; Mathema, B.; Vinnard, C.; Dever, L.L.; Kreiswirth, B.N. Colistin- and Carbapenem-Resistant Escherichia coli Harboring mcr-1 and bla $a_{\mathrm{NDM}-5}$, Causing a Complicated Urinary Tract Infection in a Patient from the United States: TABLE 1. mBio 2016, 7, e01191-16. [CrossRef] [PubMed]

65. Li, R.; Xie, M.; Lv, J.; Wai-Chi Chan, E.; Chen, S. Complete genetic analysis of plasmids carrying $m c r-1$ and other resistance genes in an Escherichia coli isolate of animal origin. J. Antimicrob. Chemother. 2016, 72. [CrossRef]

66. Malhotra-Kumar, S.; Xavier, B.B.; Das, A.J.; Lammens, C.; Hoang, H.T.T.; Pham, N.T.; Goossens, H. Colistin-resistant Escherichia coli harbouring mcr-1 isolated from food animals in Hanoi, Vietnam. Lancet Infect. Dis. 2016, 16, 286-287. [CrossRef] 
67. Kong, L.-H.; Lei, C.-W.; Ma, S.-Z.; Jiang, W.; Liu, B.-H.; Wang, Y.-X.; Guan, R.; Men, S.; Yuan, Q.-W.; Cheng, G.-Y.; et al. Various Sequence Types of Escherichia coli Isolates Coharboring blaNDM-5 and mcr-1 Genes from a Commercial Swine Farm in China. Antimicrob. Agents Chemother. 2017, 61, e02167-16. [CrossRef] [PubMed]

68. Li, R.; Xie, M.; Chen, K.; Dong, N.; Zhang, R.; Chen, S. Characterization of a hybrid plasmid harboring a composite transposon encoding mcr-1. (Unpublished).

69. Gao, R.; Hu, Y.; Li, Z.; Sun, J.; Wang, Q.; Lin, J.; Ye, H.; Liu, F.; Srinivas, S.; Li, D.; et al. Dissemination and Mechanism for the MCR-1 Colistin Resistance. PLOS Pathog. 2016, 12, e1005957. [CrossRef] [PubMed]

70. Zhang, C.; Feng, Y.; Liu, F.; Jiang, H.; Qu, Z.; Lei, M.; Wang, J.; Zhang, B.; Hu, Y.; Ding, J.; Zhu, B. A Phage-Like IncY Plasmid Carrying the mcr-1 Gene in Escherichia coli from a Pig Farm in China. Antimicrob. Agents Chemother. 2017, 61. [CrossRef] [PubMed]

71. Pham Thanh, D.; Thanh Tuyen, H.; Nguyen Thi Nguyen, T.; Chung The, H.; Wick, R.R.; Thwaites, G.E.; Baker, S.; Holt, K.E. Inducible colistin resistance via a disrupted plasmid-borne mcr-1 gene in a 2008 Vietnamese Shigella sonnei isolate. J. Antimicrob. Chemother. 2016, 71, 2314-2317. [CrossRef] [PubMed]

72. Donà, V.; Bernasconi, O.J.; Pires, J.; Collaud, A.; Overesch, G.; Ramette, A.; Perreten, V.; Endimiani, A. Heterogeneous Genetic Location of $m c r-1$ in Colistin-Resistant Escherichia coli Isolated from Humans and Retail Chicken Meat in Switzerland: Emergence of mor-1 -Carrying IncK2 Plasmids. Antimicrob. Agents Chemother. 2017. [CrossRef] [PubMed]

73. Seiffert, S.N.; Carattoli, A.; Schwendener, S.; Collaud, A.; Endimiani, A.; Perreten, V. Plasmids Carrying blaCMY -2/4 in Escherichia coli from Poultry, Poultry Meat, and Humans Belong to a Novel IncK Subgroup Designated IncK2. Front. Microbiol. 2017, 8, 407. [CrossRef] [PubMed]

74. Zurfluh, K.; Nüesch-Inderbinen, M.; Klumpp, J.; Poirel, L.; Nordmann, P.; Stephan, R. Key features of mcr-1-bearing plasmids from Escherichia coli isolated from humans and food. Antimicrob. Resist. Infect. Control 2017, 6, 91. [CrossRef] [PubMed]

75. Szabó, M.; Kiss, J.; Kótány, G.; Olasz, F. Importance of illegitimate recombination and transposition in IS30-associated excision events. Plasmid 1999, 42, 192-209. [CrossRef] [PubMed]

76. Chevalier, B.S. Homing endonucleases: Structural and functional insight into the catalysts of intron/intein mobility. Nucleic Acids Res. 2001, 29, 3757-3774. [CrossRef] [PubMed] 